\title{
THE RELEVANCE OF CREATION AND RIGHTEOUSNESS TO INTERVENTION FOR THE POOR AND NEEDY IN THE OLD TESTAMENT ${ }^{1}$
}

\author{
Richard W. Neville
}

This study originated with an interest in explaining the fact that intervention for the vulnerable elements of society in the Old Testament is frequently associated with the roots שפטט צדת and It eventually led to a broader interest in the basis of intervention for the poor and needy in the OT. Both the spatial and temporal constraints of the dissertation meant it was necessary to narrow the area of study considerably. The original interest in the relevance of

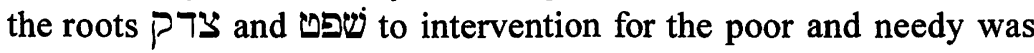
retained. To this was added a study of the relevance of human creation to the ethic of intervention for the vulnerable in the OT.

Part One of the dissertation investigates the theme of the relevance of human creation to intervention for the poor and needy, and consists of nine chapters. The first six are concerned with human creation as it is presented in Genesis 1, and the last three are concerned with the creation of human beings in the womb.

Genesis 1 records the creation of man in God's image and this idea is echoed in Genesis 5 and 9. These three texts exhaust the biblical references to the concept of man as created in God's image. Nevertheless, the fact that man was created in God's image is potentially a powerful basis for advocating the proper treatment of human beings. Surprisingly, Genesis 9:6 is the only Old Testament text to explicitly invoke man's creation in God's image to establish a principle governing the treatment of human beings. This is enough, however, to justify an examination of Genesis 9:1-6 in an attempt to understand the nature of the connection the writer makes between human creation and the treatment of human beings.

1 R.W. Neville, The Relevance of Creation and Righteousness to Intervention for the Poor and Needy in the Old Testament (unpublished Ph.D. thesis, University of Cambridge, 2001); supervisor: Prof. J.A. Emerton. 
In order to understand Genesis 9:6 it was also necessary to come to some kind of understanding of Genesis 1:26-28 and Genesis 5:1-3. In order to understand how human creation could serve as a basis for the proper treatment of human beings, it was necessary to understand how the writer of these texts (all assigned to the priestly source) portrays human creation. How was it that human creation endowed human life with the value it appears to have in Genesis 9:6? Simply pointing out that humans were 'created in God's image' only begs the further question, 'what does "created in God's image" mean?' Chapters 1 to 6 take up these questions in an attempt to understand the connection between human creation and the treatment of human beings in Genesis 9:6.

The other important tradition within the theme of human creation in the OT is concerned with the creation of the individual in the womb. Several texts invoke this tradition as a basis for the proper treatment of the vulnerable. Once again this study proceeds with an investigation of the nature and significance of this kind of creation, before considering how it came to function as the basis for the proper treatment of the vulnerable.

It is clear from the texts studied in Part One, that the theme of human creation served as a basis for the proper treatment of human beings. Both the creation of mankind in the beginning, and the creation of the human individual in the womb, feature as reasons for the proper treatment of human beings. The creation of man in the beginning is used in Genesis 9:6 to establish the value of all human life. The creation of the individual in the womb occurs in texts that deal specifically with the treatment of vulnerable individuals.

Part One concludes that both traditions contain an analogy between the relationship of the creator and the human creature, and the relationship between a father and child. While these traditions are reluctant to use explicit fathering terminology, they testify to a caring relationship of this kind between the creator and his human creation. Man's creation as given in Genesis 1 distinguished him from all other creatures, and the individual's creation in the womb could be portrayed as mysterious and wonderful. However, these factors, in and of themselves, do not fully account for the association between the creation of human life and the treatment of human beings in the OT. There was also the relational element. Both as the creator of mankind, and as the creator of the individual, God established a relationship with his creature. In the context of this relationship he valued the life of his human creature, and it was this 
valuation that was to serve as a guide for the treatment of human life in general, and the treatment of the poor and needy in particular.

These findings are corroborated by what is known of the relationship between an individual and his god in Mesopotamia (Chapter 7), and by the relational and familial implications of creation in other human creation texts from Mesopotamia and Egypt (Excursus 3). The interplay of creation and procreation language in the OT (Chapter 8) provides further support for this conclusion.

Part Two of the dissertation is composed of three chapters (10-12), which attempt to explain the relevance of the roots צד and to intervention for the poor and needy.

Chapter 10 argues that the use of the language of 'rights' to translate constructions involving the root שפט (דין (and in contex dealing with intervention for the poor and needy is mistaken. The words derived from this root are better explained in terms of juridical decision (judgement) and legal cases. The concern of the poor and needy of ancient Israel was to have their complaints heard, and to have them judged rightly. They did not cry out for their rights, but for right judgement.

Chapter 11 surveys material from both Mesopotamia and Israel in order to demonstrate the importance of the language of juridical decision in expressions of intervention for the poor and needy. It is evident that the poor and needy of ancient Israel and the ancient Near East depended on the intervention of a person of power and influence in order to deliver them from oppression.

The ideal of the righteous king, capable of just judgement, is well attested in Israel (Ps. 72; $2 \mathrm{Sa} .15: 6 ; 1 \mathrm{Ki} .3: 16-28$ ) and other contemporary Near Eastern cultures. It is not surprising, then, to find that the king had a prominent role in intervention for the poor and needy. In fact, the judiciary at all levels, from the clan to the heavenly court, served as the hope of the needy individual. It was the individuals of power who adjudicated disputes and attended to complaints, and thus provided the mechanism by which a person who was being wronged could find help. This placed a premium on the character of the people who wielded power in the community. It mattered a great deal whether or not they could be relied on to hear and respond to the complaints of the vulnerable members of the community. This is why righteousness was so valued as a characteristic of community leaders.

The fact that Yahweh (in his capacity as the righteous RulerJudge) and Šamaš (the god of justice) were pre-eminently important 
to the oppressed, is also evidence for the importance of juridical intervention for the poor and needy.

It is argued in Chapter 12 that in contexts dealing with intervention for the vulnerable, derivatives of the root צד do not refer to an individual's rights, but to a quality that can characterise a person or a juridical act so as to guarantee intervention for those who are in need of it. It can also refer to the favourable verdict that brings deliverance to the oppressed individual.

Part Two concludes that both שיפט צמ w w w were used of actions and qualities integral to the legal process on which the poor relied for saving intervention. Because of this, both terms came to express, by means of various idioms, the cry and the hope of the poor and needy. The juridical nature of this intervention is reflected in the use

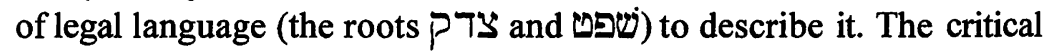
nature of this intervention is evident from the fact that these roots developed connotations of deliverance and salvation.

In Israel, at least, where the town gate served as a public court room and local family heads served as the first level of the judiciary, it is not surprising to find so much juridical language had passed into the vocabulary of daily life. When this is combined with the fact that a dominant theological theme conceived of Yahweh as the heavenly Ruler-Judge who governed creation righteously from his heavenly court, it is also understandable that so much of the nation's life, and even the individual's prayer life, made use of this same forensic vocabulary and thought. 